\title{
GCU
}

Glasgow Caledonian

University

University for the Common Good

\section{The implementation of Saudization in the hotel industry}

\author{
Azhar, Areej; Duncan, Peter; Edgar, David
}

Published in:

Journal of Human Resources in Hospitality and Tourism

DOI:

$10.1080 / 15332845.2017 .1406271$

Publication date:

2018

Document Version

Author accepted manuscript

Link to publication in ResearchOnline

Citation for published version (Harvard):

Azhar, A, Duncan, P \& Edgar, D 2018, 'The implementation of Saudization in the hotel industry', Journal of Human Resources in Hospitality and Tourism, vol. 17, no. 2, pp. 222-246.

https://doi.org/10.1080/15332845.2017.1406271

\section{General rights}

Copyright and moral rights for the publications made accessible in the public portal are retained by the authors and/or other copyright owners and it is a condition of accessing publications that users recognise and abide by the legal requirements associated with these rights.

Take down policy

If you believe that this document breaches copyright please view our takedown policy at https://edshare.gcu.ac.uk/id/eprint/5179 for details of how to contact us. 


\section{The Implementation of Saudization in the Hotel Industry}

Areej Azhar MSc ${ }^{1}$

Glasgow School for Business and Society, Glasgow Caledonian University, Glasgow, UK Tel: 00441412731897

E-mail: aazhar13@caledonian.ac.uk

Dr Peter Duncan PhD

Glasgow School for Business and Society, Glasgow Caledonian University, Glasgow, UK Tel: 00441413313723

E-mail: p.b.duncan@gcu.ac.uk

Professor David Edgar PhD

Glasgow School for Business and Society, Glasgow Caledonian University, Glasgow, UK Tel: 00441413313180

E-mail: d.a.edgar@gcu.ac.uk

${ }^{1}$ Corresponding author

Word count: 8446 (excluding abstract and references) 


\begin{abstract}
Saudi Arabia's localization policy, Saudization, aims to decrease reliance on expatriate workers, but it has been more successful in the public sector than in the private sector. This study explores the issues involved in effectively implementing the policy in the 4- and 5-star hotel industry in Saudi Arabia. Tourism professionals, HR professionals and hotel managers were interviewed and hotel managers and employees surveyed. The research specifies the criteria for the effective implementation of Saudization, identifies the issues involved in implementing the Saudization policy in the 4- and 5-star hotel industry, determines factors and makes recommendations which could assist in implementing the policy effectively in this industry.
\end{abstract}

KEYWORDS - Saudi Arabia; localization; Saudization; hotels

\title{
INTRODUCTION
}

The Gulf Co-operation Council (GCC) consists of Bahrain, Kuwait, Oman, Qatar, Saudi Arabia and the United Arab Emirates (Harry, 2007). All the GCC countries have high rates of unemployment among locals, but employ many expatriate workers (Singh, Jones, \& Hall, 2012). Hence, localization policies have been developed to replace foreign workers with locals (Mashood, Verhoeven, \& Chansarkar, 2009). Hines (2014) defines localization as “a process which reverses the trend of globalization by discriminating in favor of the local" (p.4). Saudi Arabia has the longest established localization policy of all the GCC states (Mashood et al., 2009) and forms the basis of this paper.

Non-Saudis constitute a significant proportion of the population of Saudi Arabia. For example, in 2015, from a total population of 30,770,375, almost one-third were non-Saudi, while unemployment among Saudi nationals stood at 11.5\% (General Authority for Statistics, 2015). This led to the introduction in 1970 of a localization policy, termed Saudization. However, while Saudization has been successful in terms of the high proportion of Saudi workers employed in the public sector, it has been less successful in the private sector. Why might this be? What are the issues involved in attempting to achieve the effective implementation of the localization policy in the private sector in Saudi Arabia? Rather than 
focusing on the private sector as a whole, this paper investigates the hotel industry (specifically 4- and 5- star hotels). Hence, the purpose of this paper is to explore the issues involved in effectively implementing the Saudization policy in the 4- and 5-star hotel industry in Saudi Arabia. The specific objectives are to:

1. Specify criteria for the effective implementation of the Saudization policy;

2. Identify issues involved in implementing the Saudization policy in the 4- and 5-star hotel industry;

3. Determine factors which could assist in implementing the policy in this industry effectively.

\section{LITERATURE REVIEW}

\section{Background}

This section has two purposes: first, to understand the nature and impact of Saudization by exploring the rationale behind the Saudization policy, as well as the specifics of the policy and its implementation, and second, to profile the hotel industry in Saudi Arabia, as this forms the context of the research.

\section{Localization Policy in Saudi Arabia}

Saudi Arabia is heavily reliant on expatriate workers (Al-Asfour \& Khan 2014). However, increasingly large numbers of young people are and seeking employment, squeezing the employment market.

There has also been an increase in Saudi women's participation in higher education and concomitantly, in the workforce, leading to pressure to provide jobs for them. However, cultural restrictions still prevail and women remain largely confined to traditional types of work such as teaching (Sullivan, 2012). Moreover, men and women are segregated in places 
of education, in social life and in the majority of workplaces (Jamjoom \& Kelly, 2013). Many women would not consider a job involving direct face-to-face contact with men (Leeth, 2014), which Qureshi (2014) attributes to preferences resulting from respect for religious teachings.

A further factor in the Saudi government's introduction of the localization policy is that it would like to reduce the amount of money leaving the country via expatriates. According to an International Monetary Fund (IMF) (2013) study, remittances sent by expatriate workers in Saudi Arabia to their home countries in 2011 accounted for $6.2 \%$ of Saudi Arabia's gross domestic product (GDP) of US\$927.8 billion. Moreover, there is a need for Saudi Arabia to diversify its economy, which has been almost entirely reliant on oil until relatively recently (Albassam, 2015). These are the key reasons leading to the development of the Saudization policy in Saudi Arabia.

The Saudi government's first Five-Year Development Plan (1970-75) decreed that 75\% of workers should be Saudis and $51 \%$ of total salaries paid should be to Saudi workers in all businesses as a target to be met by the end of the plan (Fakeeh, 2009). However, the decree was not enforced at that time because almost all Saudis were interested in working only for the public sector, and over the next two decades, the public sector was able to absorb the national workforce (Alsheikh, 2015). The concept of building a pool of Saudi labor in the private sector did not become a priority until the end of the $20^{\text {th }}$ century (Fakeeh, 2009).

The Saudization policy proved successful in terms of the high proportion of Saudi employees in the public sector, but this sector became saturated (Baqadir, Patrick, \& Burns, 2011). Hence, since 2000, the Saudi government has placed the onus on the private sector to replace foreign workers with locals (Al-Asfour \& Khan, 2014). The Saudi government's Eighth Development Plan (2006-2010) set a quota of a 30\% Saudization rate in the private 
sector by 2010 (Alsheikh, 2015). However, this quota was not achieved and Saudis' employment share in the private sector had reached only $10.4 \%$ by 2010 (Alsheikh, 2015). Al-Asfour and Khan (2014) suggest that implementation of the localization policy in the public sector has met with greater success than in the private sector as public sector employees tend to receive higher salaries, have greater job security, more generous holidays, work fewer hours, and, in general, the work is less demanding. Further, Albabtain (2015) claims that Saudis prefer to work in the public sector because it offers jobs with higher social status, and that status is one of the most important factors for Saudis in their choice of employment. Indeed, Al-Asfour and Khan (2014) state that many Saudis want to receive middle to upper level management positions subsequent to graduating from college; the public sector provides this opportunity (Baki, 2004).

In 2011, the government increased the emphasis on Saudization through the Nitaqat programme (Peck, 2015). The idea behind the Nitaqat programme is that, while the quota system previously in force was difficult to comply with due to skill shortages in the labor market, a programme that creates a 'race' to Saudization will drive the changes that are needed in that labor market over the long term (DLA Piper, 2012). The Nitaqat programme categorizes private companies into red, yellow, green and platinum (exceptional) bands, according to their Saudization rate. Organizations graded as red are considered to be noncompliant, yellow signifies low compliance, the green band shows a high level of compliance, and those in the platinum band are deemed as having exceptional compliance (Hay Group, 2012). The specifications for the bands are different for different industries.

The programme has proved controversial however, as companies falling into the red and yellow categories face punitive measures (Alshanbri, Khalfan, \& Maqsood, 2014). Redbanded companies are not able to renew their foreign workers' visas or hire any more foreign 
workers; while yellow-banded companies cannot extend their foreign employees' work visas beyond six years (Aldosari, 2013). However, companies classified as platinum and green are compliant with the Saudization requirements for their category and receive benefits, such as the ability to obtain and renew work permits in relation to foreign employees (Aldosari, 2013).

However, a problem with the Nitaqat programme is that it measures the effectiveness of Saudization in quantitative terms only, without taking into account its qualitative aspect. In this respect, Potter (1989) argues that the effectiveness of the localization process refers not only to the extent to which jobs originally held by expatriates are filled by local employees, but whether they are filled by local employees who are competent to undertake the job. This is a critical observation in that human resources are a vital element in a nation's potential for economic development (Todaro \& Smith, 2006). It is therefore essential for existing competencies to be developed in a Saudized labor force in order for the Saudization policy to be implemented effectively (Todaro \& Smith, 2006). Turning to the focus of this paper, Saudization in four- and five-star hotels, it is useful first to give an overview of the hotel industry in Saudi Arabia.

\section{Hotel Industry in Saudi Arabia}

There were 1,446 hotels of all grades in Saudi Arabia in 2015 (MAS, 2016). Mecca and Medina are the destination for some five million pilgrims each year for the public Hajj or the personal Umrah pilgrimages (Brdesee, Corbitt, Pittayachawan, Alsaggaf, \& Brooks, 2012) and therefore hotels in these cities are mainly occupied by pilgrims. Otherwise, the main markets for tourism in Saudi Arabia are other GCC countries and the domestic market. Riyadh, as the business capital, caters mainly to the corporate segment (HVS, 2012); while Jeddah, the second-largest city in Saudi Arabia, caters for both domestic tourists and business 
travellers (Aljazira Capital, 2015). The Saudi government has recognized that the real tourism opportunity for the country lies in growing domestic tourism market (Yusuf, 2014) and is committed to substantially increasing it to retain some of the money spent by the 8.2 million Saudi residents who currently travel abroad each year (Collier's International Tourism, 2014).

To meet the demand for accommodation associated with growing tourism, there has been an increase in four- and five-star hotels developed in the region (HVS, 2012). However, in 2011, out of a total of 51,482 jobs in the hotel industry in Saudi Arabia, 41,724 (81\%) were taken by non-Saudis, while Saudis took the remaining 9,758 (19\%) (MAS, 2011). Table 1 below shows the Nitaqat bands for the Lodging and Hotels industry. Note that, as defined by the Saudi government, the industry includes lodgings (short-term rented accommodation, seaside chalets and so on), as well as hotels (Saudi Ministry of Labor, 2014).

Table 1: Guide to Nitaqat Bands for the Lodging and Hotels Industry (Al Ahsa Chamber, 2014). The percentages indicate the percentage of Saudi employees required for each band.

\begin{tabular}{|l|c|c|c|c|}
\hline Business Size (No. of employees) & Red & Yellow & Green & Platinum \\
\hline Small $(10-49)$ & $0-5 \%$ & $6-19 \%$ & $20-36 \%$ & $\geq 37 \%$ \\
\hline Medium $(50-499)$ & $0-7 \%$ & $8-29 \%$ & $30-49 \%$ & $\geq 50 \%$ \\
\hline Large $(500-2,999)$ & $0-9 \%$ & $10-33 \%$ & $34-52 \%$ & $\geq 53 \%$ \\
\hline Huge $(3,000+)$ & $0-9 \%$ & $10-33 \%$ & $34-52 \%$ & $\geq 53 \%$ \\
\hline
\end{tabular}

Despite the growth and major employment prospects offered by the hotel industry in Saudi Arabia, relatively few Saudis see any real career opportunities in the industry. This may be due to a number of factors, ranging from career expectations and education to the industry employment conditions and social status.

Shediac, Hoteit, and Jamjoom (2013) found that school students in GCC countries receive little critical information or guidance on preparing for higher education or their future careers. In Saudi Arabia specifically, Fakeeh (2009) states that career planning is not an 
integral part of education. Nonethelees, Aljubaili (2015) contends that the Saudi government is intent on encouraging more Saudi students to study tourism.

Regarding formal training in tourism and hospitality, there are currently six public and seven private colleges in Saudi Arabia offering Bachelor and two-year diploma degrees in the tourism and hospitality fields (Aljubaili, 2015). However, Mayaka and Akama (2007) suggest that the perceived low status of tourism as an academic discipline has frequently led to the view of such courses as being a way of increasing student enrolment, without sufficient consideration being given to the quality of outcomes for these programmes. A qualification in tourism and hospitality from a Saudi college may not necessarily be perceived as a guarantee of competence in the field.

The hospitality sector is seen as badly paid, low status employment, with irregular and often unsociable working hours and is therefore unattractive to Saudis (Aldosari, 2013). In sum, while Saudi nationals are in great demand in the hotel industry to fulfill the governmentimposed Nitaqat quotas, it can be difficult to find suitably qualified Saudis prepared to take employment in what may be perceived as more unattractive positions.

\section{METHODOLOGY}

The research adopted a case study of the 4- and 5-star hotel industry in Saudi Arabia, using a pragmatist paradigm with an abductive approach to make sense of the experiences of stakeholders working in the 4- and 5-star hotel industry in Saudi Arabia. The 4- and 5-star hotel industry in Saudi Arabia was chosen as the case for this research, as the hotel industry has become very important in the economy of the country (Collier's International Tourism, 2014) and is among the world's top ten countries for hotel projects under development (Hussain, 2015). Mixed methods, combining qualitative and quantitative techniques, allowed data to be collected from questionnaires and interviews and triangulated. 


\section{Instruments}

The empirical data collection was carried out in two phases. Phase I consisted of unstructured interviews which were conducted to gain a pre-understanding of the issues involved in the

research, as Gummesson (2000) suggests. Phase II consisted of a questionnaire with 15 statements developed from the themes emerging from Phase I and the literature, about which respondents were asked to agree/disagree on a 5-point Likert scale, as well as a single openended question at the end of the instrument. This open-ended question was 'Can you please give a reason for your choice of answer to Statement 7?'. Statement 7 was 'The localization policy in the hotel industry could be improved' (see Table 4). The questionnaires were written in English, and then translated by one of the authors (a Saudi national and native Arabic speaker/writer) into Arabic for the Arabic-speaking respondents. A linguistic expert, without having seen the originals, was asked to translate the Arabic translations into English. These English translations were then compared to the original English versions to see if there were any significant differences between them. No significant differences were found, indicating that the author's Arabic translation of the original questionnaires was accurate.

\section{Sample and Data Collection}

The Phase I interviews were conducted with three officials of the Saudi Commission for Tourism and Antiquities (SCTA) (renamed the Saudi Commission for Tourism and National Heritage in July 2015), and one official from the Saudi Human Resource Development Fund (SHRDF). The questionnaire in Phase II was administered personally by the researcher to 24 managers and 24 employees in twelve, 4- and 5-star hotels in the Saudi Arabian cities of Jeddah and Riyadh. These cities were chosen because they are the two largest cities in the country. The hotels chosen were of varying sizes; a few were locally owned, while the majority belonged to international chains. 


\section{Data Analysis}

The data obtained from the Phase I interviews were analysed using thematic analysis and the themes which emerged were used to develop the Phase II questionnaire statements. The data from the questionnaire statements were analysed using the SPSS program to obtain frequencies, percentages and means, while those from the open-ended question in the questionnaire were analysed using thematic analysis.

\section{FINDINGS AND DISCUSSION}

\section{Phase I: Interviews}

In this section, the data gathered and analysed from Phase I of the empirical work are presented and discussed. The themes which emerged from the thematic analysis of the Phase I data are shown in Figure 1, clockwise from the top in alphabetical order.

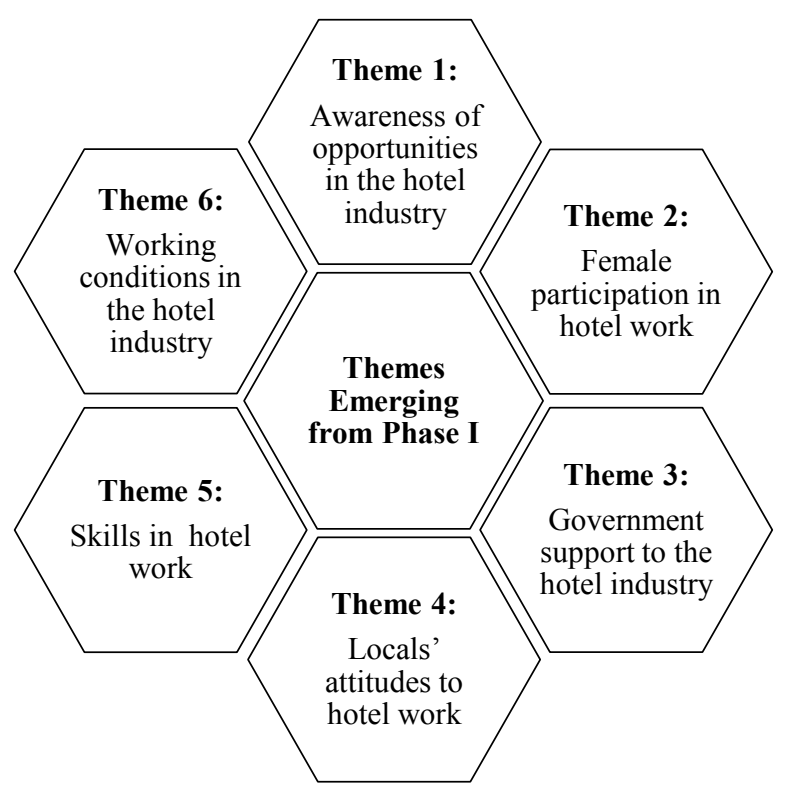

Figure 1: Themes Emerging from Phase I 


\section{Theme 1: Awareness of opportunities in the hotel industry}

The Saudi Human Resource Development Fund (SHRDF) official stated that Saudis appear to be unaware of the possibility of having a good career in the hotel industry. As no Saudis worked in hotels until comparatively recently, the perception may have arisen that hotel work is only suitable for foreigners. This finding supports Fakeeh's (2009) suggestion that career planning is not an integral part of the education system in Saudi Arabia. Thus, it can be inferred that there is lack of awareness, particularly among young people, of the potential of careers in the hotel industry, representing an issue in the implementation of the Saudization policy in the 4- and 5-star hotel industry.

\section{Theme 2: Female participation in hotel work}

There are currently very few Saudi women working in hotels. The SHRDF official spoke of how the employment of Saudi women in hotels could help fulfill Saudization quotas, highlighting that, to encourage more women to work in hotels, the office space and facilities would have to be separate from male employees. He believed that in order to encourage more Saudi women into hotel employment, hotel management should carefully manage women's working hours, as, for example, working late at night is not suitable for women in Saudi culture. One of the officials (SCTA1) from the Saudi Commission for Tourism and Antiquities (SCTA) also spoke of the cultural restrictions to the employment of Saudi women in hotels. The findings support the contention that certain types of job, including many types of hotel work, are seen as unsuitable for women in Saudi culture, that many women would not wish to work in a mixed-gender environment (Alotaibi, Paliadelis \& Valenzuela, 2015) or that their families would not accept their doing so (Redvers, 2015). Scarcity of Saudi women in hotel work is therefore identified as an issue involved in implementing the Saudization policy in the 4- and 5-star hotel industry. 


\section{Theme 3: Government support for the hotel industry}

The SHRDF official spoke of the SHRDF scheme to pay a percentage of the salary of any Saudi trainee who is hired by any hotel after he or she finishes training, or for any new recruit of the firm. This subsidy serves to encourage hotels to employ Saudis, while at the same time it is intended to raise salaries to a level likely to attract Saudis to hotel work. SCTA1 also spoke of the subsidy, explaining that the amount of this wage subsidy depends on the status of the hotel in question; that is, it varies according to the position of the employee, and on the hotel's Nitaqat classification. However, SCTA3 pointed sometimes hotels could not find suitable Saudi candidates and had to employ any Saudi to make up the Nitaqat quota. This finding is consistent with Peck's (2015) finding that many private sector industries had great difficulty in finding enough Saudi employees to make up the Nitaqat quota. Hence, difficulty in fulfilling Nitaqat quotas is identified as an issue in the implementation of Saudization in 4and 5-star hotels.

\section{Theme 4: Locals' attitudes to hotel work}

SCTA2 expressed the view that Saudis had no conception of career progression and wanted to go straight into employment at managerial level, which is not possible in the hotel industry or indeed, in the private sector in general. This finding supports Al-Asfour and Khan's (2014) claim that many Saudis want to enter middle to upper level management positions directly after graduating from college. SCTA3 pointed out that despite the government subsidies, there were still not enough suitable Saudi candidates for hotel work. Further, he suggested that hotel managers often had a perception that Saudis were not as hard working or reliable as foreign workers, reflecting Baqadir's (2013) finding that many Saudi private sector employers considered Saudis lazy and unreliable. Locals' attitudes are therefore identified as an issue involved in the implementation of the Saudization policy in 4- and 5-star hotels. 


\section{Theme 5: Skills in hotel work}

SCTA3 stated that hotel managers were often reluctant to give training to Saudi employees as they felt that when the employees had benefited for this training they might then leave and take up a better job in another hotel. This finding is consistent with Al-Munajjed and Sabbagh (2011), who found that private sector employers see skilled expatriates as offering greater value for money than employing Saudis who must undergo extensive training. The SHRDF official suggested that education and training in the Saudi Arabia were not well aligned with the needs of the hotel industry and that, more specifically, Saudis tended to have poor English language skills. English language skills are important for hotel employees, as a good command of the English language enables hotel employees to communicate more effectively with international tourists and provide better customer service, thereby improving guest satisfaction (Bobanovic \& Grzinic, 2011). Communication skills such as language skills are among the soft skills (Robles, 2012), which Warhurst and Nickson (2007) argue, are essential in the hotel industry. However, this finding supports Patrick's (2014) contention that in Saudi Arabia, neither the education system nor the prevailing culture emphasise the development of soft skills. Skills shortage is therefore identified as an issue in the implementation of Saudization in 4- and 5-star hotels.

\section{Theme 6: Working conditions in the hotel industry}

SCTA1 explained that working hours in the public sector were shorter than those in the private sector, and that flexible and part-time working practices were not widely used in Saudi Arabia. This is consistent with Scott-Jackson et al.'s (2013) report that part-time and flexible work options are virtually unknown in Saudi Arabia. SCTA1 also highlighted that there was a perception that job security was greater in the public sector than in the private sector. However, this perception of greater job security may be incorrect, as there are strict 
regulations in Saudis Arabia concerning the dismissal of locals in both public and private sectors; it is not an easy process (DLA Piper, 2015).

SCTA2 and SCTA3 pointed out that employees in the public sector were given more holidays than those in the private sector. SHRDF argued that if salaries were higher for hotel work, this would attract more Saudis, but that this would be expensive for hotels and they might have to put their rates up to compensate for the extra outlay. The disparity between conditions in the public and private sectors is therefore identified as an issue involved in the implementation of Saudization in the 4- and 5-star hotel industry.

\section{Phase II: Questionnaire}

The themes which emerged from the Phase 1 interview data were used to develop the 15 closed-ended Likert scale statements. Statements 1 and 2 relate to Theme 1, Statement 3 to Theme 2, Statements 4, 5, 6, and 7 to Theme 3 and Statements 8, 9 and 10 to Theme 4 . Statements 11, 12 and 13 and Statements 14 and 15 were developed to correspond to Themes 5 and 6 , respectively. These statements and the results of the analysis of the responses to them are shown in Tables 2 to 7 . The results of the open-ended question at the end of questionnaire were analysed using thematic analysis and the same themes emerged as had emerged in Phase I. However, it should be noted that Themes 2 and 4 emerged only from the managers' responses to this question, and not from those of the employees.

\section{Theme 1: Awareness of opportunities in the hotel industry}

The Likert scale statements relating to Theme 1, Awareness of opportunities in the hotel industry, are shown in Table 2 , together with the results of the analysis of the responses to these statements. Following this, the results of the responses to the open-ended question in which this theme emerged are also presented. 
Table 2: Results of analysis of responses for Theme 1: Awareness of opportunities in the hotel industry.

\begin{tabular}{|c|c|c|c|c|c|c|c|c|c|c|}
\hline & Statements & Position & & $\begin{array}{l}\text { Strongly } \\
\text { Disagree }\end{array}$ & Disagree & $\begin{array}{l}\text { Neither Agree } \\
\text { Nor Disagree }\end{array}$ & Agree & $\begin{array}{l}\text { Strongly } \\
\text { Agree }\end{array}$ & Total & Mean \\
\hline \multirow{4}{*}{1} & \multirow{4}{*}{$\begin{array}{l}\text { Saudis can achieve } \\
\text { their career ambitions } \\
\text { in the hotel sector. }\end{array}$} & \multirow{2}{*}{ Managers } & Frequency & 0 & 1 & 5 & 16 & 2 & 24 & \multirow{2}{*}{3.79} \\
\hline & & & Percent & $0.0 \%$ & $4.2 \%$ & $20.8 \%$ & $66.7 \%$ & $8.3 \%$ & $100 \%$ & \\
\hline & & \multirow{2}{*}{ Employees } & Frequency & 1 & 9 & 6 & 6 & 2 & 24 & \multirow{2}{*}{2.96} \\
\hline & & & Percent & $4.2 \%$ & $37.5 \%$ & $25.0 \%$ & $25.0 \%$ & $8.3 \%$ & $100 \%$ & \\
\hline \multirow{4}{*}{2} & \multirow{4}{*}{$\begin{array}{l}\text { There are good } \\
\text { opportunities for } \\
\text { promotion in hotel } \\
\text { work. }\end{array}$} & \multirow{2}{*}{ Managers } & Frequency & 0 & 0 & 1 & 18 & 5 & 24 & \multirow{2}{*}{4.17} \\
\hline & & & Percent & $0.0 \%$ & $0.0 \%$ & $4.2 \%$ & $75.0 \%$ & $20.8 \%$ & $100 \%$ & \\
\hline & & \multirow{2}{*}{ Employees } & Frequency & 0 & 3 & 4 & 14 & 3 & 24 & \multirow{2}{*}{3.71} \\
\hline & & & Percent & $0.0 \%$ & $12.5 \%$ & $16.7 \%$ & $58.3 \%$ & $12.5 \%$ & $100 \%$ & \\
\hline
\end{tabular}

As shown in Table 2, for Statement 1 three-quarters of the managers agreed or strongly agreed that Saudis could achieve their career ambitions in the hotel industry. In contrast, only one-third of the employees gave the same responses. There was a similar difference in the responses to Statement 2, as $95.8 \%$ of managers agreed or strongly agreed that there were good opportunities for promotion in hotel work, whereas only $70.8 \%$ of employees did so.

The differences in the mean scores of the managers and the employees for both of these statements indicate the disparity in the perspectives of managers and employees regarding awareness of the potential for having a good career in hotel work. These differences could be attributed to managers having already achieved a promoted/'high' position, while employees may perceive that their careers are not advancing rapidly enough.

With few Saudis applying for hotel jobs, there is a limited pool from which hotel managers can recruit, making it more difficult to fulfill quotas and implement Saudization. It appears that perceptions of the potential for a good career in the hotel industry are low. To overcome this, Manager 20, in response to the open-ended question suggested

There should be a long-term plan to raise awareness of opportunities in hotel work and to inform people about such work. (M20)

Similarly, Employee 14 suggested that 
Schools and colleges should make Saudis aware of the possibilities of having a good career in hotel work. (E14)

The implication of the findings is that raising awareness of the potential a career in the hotel industry is a factor that could assist in implementing the policy in this industry effectively.

\section{Theme 2: Female participation in hotel work}

The Likert scale statements relating to Theme 2, Female participation in hotel work, are shown in Table 3, together with the results of the analysis of the responses to these statements. Following this, the results of the responses to the open-ended question in which this theme emerged are also presented.

Table 3: Results of analysis of responses for Theme 2: Female participation in hotel work

\begin{tabular}{|c|c|c|c|c|c|c|c|c|c|c|}
\hline & Statements & Position & & $\begin{array}{l}\text { Strongly } \\
\text { Disagree }\end{array}$ & Disagree & $\begin{array}{l}\text { Neither Agree } \\
\text { Nor Disagree }\end{array}$ & Agree & $\begin{array}{l}\text { Strongly } \\
\text { Agree }\end{array}$ & Total & Mean \\
\hline \multirow{4}{*}{3} & \multirow{4}{*}{$\begin{array}{l}\text { The mixed-gender } \\
\text { environment in hotel } \\
\text { work is unsuitable for } \\
\text { Saudi women. }\end{array}$} & \multirow{2}{*}{ Managers } & Frequency & 5 & 6 & 8 & 2 & 3 & 24 & \multirow{2}{*}{2.67} \\
\hline & & & Percent & $20.8 \%$ & $25 \%$ & $33.3 \%$ & $8.3 \%$ & $12.5 \%$ & $100 \%$ & \\
\hline & & \multirow{2}{*}{ Employees } & Frequency & 6 & 5 & 4 & 5 & 4 & 24 & \multirow{2}{*}{2.83} \\
\hline & & & Percent & $25.0 \%$ & $20.8 \%$ & $16.7 \%$ & $20.8 \%$ & $16.7 \%$ & $100 \%$ & \\
\hline
\end{tabular}

In Statement 3, exploring the cultural restrictions, just $20.8 \%$ of the managers and $37.5 \%$ of the employees agreed or strongly agreed that the mixed-gender environment in hotel work was unsuitable for Saudi women. The same percentage $(45.8 \%)$ of both managers and employees disagreed or strongly disagreed. These responses indicate that the influence of conservative Saudi culture, which views certain types of employment as unsuitable for women, are present among those engaged in hotel work, with the slight difference $(0.16)$ between the mean scores of the managers and employees indicating that the managers and the employees have similar opinions on this issue.

In response to the open-ended question, Manager 18 expressed the opinion that 
There should be more openings for women in hotels, with allowances made for our Saudi culture. If more women worked in hotels, this would increase Saudization. (M18)

The findings confirm Mehdizadeh's (2011) argument that female employment rates in the Middle East are closely related to societal norms the type of work considered suitable for women. Hence, while the findings suggest that an increase in Saudi women's participation in the hotel workforce is a factor that could assist in implementing the policy in this industry effectively, they also reveal that cultural restrictions still prevail.

\section{Theme 3: Government support for the hotel industry}

The Likert scale statements relating to Theme 3, Government support to the hotel industry, are shown in Table 4, together with the results of the analysis of the responses to these statements. Following this, the results of the responses to the open-ended question from this theme emerged are presented.

Table 4: Results of analysis of responses for Theme 3: Government support to the hotel industry

\begin{tabular}{|c|c|c|c|c|c|c|c|c|c|c|}
\hline & Statements & Position & & $\begin{array}{l}\text { Strongly } \\
\text { Disagree }\end{array}$ & Disagree & $\begin{array}{l}\text { Neither Agree } \\
\text { Nor Disagree }\end{array}$ & Agree & $\begin{array}{l}\text { Strongly } \\
\text { Agree }\end{array}$ & Total & Mean \\
\hline \multirow{4}{*}{4} & \multirow{4}{*}{$\begin{array}{l}\text { High unemployment } \\
\text { justifies localisation. }\end{array}$} & \multirow{2}{*}{ Managers } & Frequency & 0 & 2 & 3 & 7 & 12 & 24 & \multirow{2}{*}{4.21} \\
\hline & & & Percent & $0.0 \%$ & $8.3 \%$ & $12.5 \%$ & $29.2 \%$ & $50 \%$ & $100 \%$ & \\
\hline & & \multirow{2}{*}{ Employees } & Frequency & 2 & 2 & 2 & 11 & 7 & 24 & \multirow{2}{*}{3.79} \\
\hline & & & Percent & $8.3 \%$ & $8.3 \%$ & $8.3 \%$ & $45.8 \%$ & $29.2 \%$ & $100 \%$ & \\
\hline \multirow{4}{*}{5} & \multirow{4}{*}{$\begin{array}{l}\text { Overall, localisation } \\
\text { policy is implemented } \\
\text { well. }\end{array}$} & \multirow{2}{*}{ Managers } & Frequency & 0 & 3 & 1 & 15 & 5 & 24 & \multirow{2}{*}{3.92} \\
\hline & & & Percent & $0.0 \%$ & $12.5 \%$ & $4.2 \%$ & $62.5 \%$ & $20.8 \%$ & $100 \%$ & \\
\hline & & \multirow{2}{*}{ Employees } & Frequency & 0 & 4 & 3 & 14 & 3 & 24 & \multirow{2}{*}{3.67} \\
\hline & & & Percent & $0.0 \%$ & $16.7 \%$ & $12.5 \%$ & $58.3 \%$ & $12.5 \%$ & $100 \%$ & \\
\hline \multirow{4}{*}{6} & \multirow{4}{*}{$\begin{array}{l}\text { Localisation will be } \\
\text { profitable for the hotel } \\
\text { sector in the long } \\
\text { term. }\end{array}$} & \multirow{2}{*}{ Managers } & Frequency & 0 & 1 & 3 & 16 & 4 & 24 & \multirow{2}{*}{3.96} \\
\hline & & & Percent & $0.0 \%$ & $4.2 \%$ & $12.5 \%$ & $66.7 \%$ & $16.6 \%$ & $100 \%$ & \\
\hline & & \multirow{2}{*}{ Employees } & Frequency & 0 & 4 & 4 & 12 & 4 & 24 & \multirow{2}{*}{3.67} \\
\hline & & & Percent & $0.0 \%$ & $16.7 \%$ & $16.7 \%$ & $50.0 \%$ & $16.7 \%$ & $100 \%$ & \\
\hline \multirow{4}{*}{7} & \multirow{4}{*}{$\begin{array}{l}\text { The localisation } \\
\text { policy in the hotel } \\
\text { sector could be } \\
\text { improved. }\end{array}$} & \multirow{2}{*}{ Managers } & Frequency & 0 & 4 & 2 & 8 & 10 & 24 & \multirow{2}{*}{4.00} \\
\hline & & & Percent & $0.0 \%$ & $16.7 \%$ & $8.3 \%$ & $33.3 \%$ & $41.7 \%$ & $100 \%$ & \\
\hline & & \multirow{2}{*}{ Employees } & Frequency & 0 & 0 & 3 & 13 & 8 & 24 & \multirow{2}{*}{4.21} \\
\hline & & & Percent & $0.0 \%$ & $0.0 \%$ & $12.5 \%$ & $54.2 \%$ & $33.3 \%$ & $100 \%$ & \\
\hline
\end{tabular}


The analysis of the responses to Statement 4 of the questionnaire statements revealed little difference in the opinions of the managers and employees, with $79.2 \%$ of managers and $75 \%$ of employees agreeing or strongly agreeing that high unemployment justified localization. In response to Statement 5 , the majority of both managers $(83.3 \%)$ and employees $(70.8 \%)$ expressed the view that overall, the localization policy was implemented well. The responses to Statement 6 showed that $83.3 \%$ of managers agreed or strongly agreed that Saudization would be profitable for the hotel industry in the long term. The employees' responses to the same question showed them to be more cautiously optimistic, with just over two-thirds (66.7\%) agreeing or strongly agreeing. In Statement 7, the employees showed themselves to be less satisfied with the localization policy in the hotel industry than the managers, with $87.5 \%$ of the former agreeing or strongly agreeing that localization policy in the industry could be improved, in contrast to $75 \%$ of the latter. The greatest difference in mean scores for all four statements between managers and employees was only 0.42 (for statement 4), indicating that the overall opinions of the two groups of respondents regarding government support to the hotel industry were not greatly diverse.

In response to the open-ended question, Manager 11 raised the issue of the Nitaqat programme, stating

The Saudization quotas in the hotel industry should be reassessed, as it is currently very difficult for hotels to find enough local people to make up the Nitaqat quota. (M11)

This finding confirms Al-Dosari's (2013) finding that as there is no tradition of Saudis working in the hospitality sector, it is difficult for hotels to attract enough Saudi candidates.

Employee 17, responding to the open-ended question, expressed the opinion that the current wage subsidies were not sufficient to attract Saudi recruits to hotel work, stating 
Local authorities should provide support to the hotel industry by raising wage subsidies to encourage Saudis to take up jobs in hotels. (E17)

This finding reflects the report by the IMF (2013) that wage subsidies that are unlimited in duration have been used successfully in the localization policy in another GCC country, Kuwait. However, Kluve (2010) argues that while wage subsidies, can improve the employment prospects for some workers, they are not a cure for unemployment.

\section{Theme 4: Locals' attitudes to hotel work}

The Likert scale statements relating to Theme 4, Locals' attitudes to hotel work, are shown in

Table 5, together with the results of the analysis of the responses to these statements. Following this, the results of the responses to the open-ended question in which this theme emerged are also presented.

Table 5: Results of analysis of responses for Theme 4: Locals' attitudes to hotel work

\begin{tabular}{|c|c|c|c|c|c|c|c|c|c|c|}
\hline & Statements & Position & & $\begin{array}{l}\text { Strongly } \\
\text { Disagree }\end{array}$ & Disagree & $\begin{array}{l}\text { Neither Agree } \\
\text { Nor Disagree }\end{array}$ & Agree & $\begin{array}{l}\text { Strongly } \\
\text { Agree }\end{array}$ & Total & Mean \\
\hline \multirow{4}{*}{8} & \multirow{4}{*}{$\begin{array}{c}\text { The hotel's criteria for } \\
\text { employing Saudis are } \\
\text { demanding. }\end{array}$} & \multirow{2}{*}{ Managers } & Frequency & 0 & 3 & 6 & 11 & 4 & 24 & \multirow{2}{*}{3.67} \\
\hline & & & Percent & $0.0 \%$ & $12.5 \%$ & $25.0 \%$ & $45.8 \%$ & $16.7 \%$ & $100 \%$ & \\
\hline & & \multirow{2}{*}{ Employees } & Frequency & 2 & 5 & 9 & 6 & 2 & 24 & \multirow{2}{*}{3.04} \\
\hline & & & Percent & $8.3 \%$ & $20.8 \%$ & $37.5 \%$ & $25.0 \%$ & $8.3 \%$ & $100 \%$ & \\
\hline \multirow{4}{*}{9} & \multirow{2}{*}{$\begin{array}{l}\text { In general, foreign hotel } \\
\text { employees are harder } \\
\text { working than Saudis }\end{array}$} & \multirow{2}{*}{ Managers } & Frequency & 0 & 3 & 4 & 10 & 7 & 24 & \multirow{2}{*}{3.88} \\
\hline & & & Percent & $0.0 \%$ & $12.5 \%$ & $16.7 \%$ & $41.7 \%$ & $29.2 \%$ & $100 \%$ & \\
\hline & \multirow{2}{*}{$\begin{array}{l}\text { Hotel managers prefer to } \\
\text { hire foreign workers than } \\
\text { Saudis }\end{array}$} & \multirow{2}{*}{ Employees } & Frequency & 1 & 3 & 6 & 7 & 7 & 24 & \multirow{2}{*}{3.67} \\
\hline & & & Percent & $4.2 \%$ & $12.5 \%$ & $25 \%$ & $29.2 \%$ & $29.2 \%$ & $100 \%$ & \\
\hline \multirow{4}{*}{10} & \multirow{2}{*}{$\begin{array}{l}\text { Saudi hotel employees do } \\
\text { not stay in the job for long. }\end{array}$} & \multirow{2}{*}{ Managers } & Frequency & 0 & 7 & 0 & 13 & 4 & 24 & \multirow{2}{*}{3.58} \\
\hline & & & Percent & $0.0 \%$ & $29.2 \%$ & $0.0 \%$ & $54.2 \%$ & $16.7 \%$ & $100 \%$ & \\
\hline & \multirow{2}{*}{$\begin{array}{c}\text { I am likely to move to a } \\
\text { job at another hotel in the } \\
\text { near future. }\end{array}$} & \multirow{2}{*}{ Employees } & Frequency & 1 & 1 & 12 & 8 & 2 & 24 & \multirow{2}{*}{3.38} \\
\hline & & & Percent & $4.2 \%$ & $4.2 \%$ & $50.0 \%$ & $33.3 \%$ & $8.3 \%$ & $100 \%$ & \\
\hline
\end{tabular}

Statements 8, 9 and 10 in the managers' and employees' questionnaires differed, as can been seen in Table 5. For Statement 8 , while $62.5 \%$ of managers agreed or strongly agreed that criteria for employing Saudis were demanding, just over half of this percentage $(33.3 \%)$ of employees gave the same responses. This could indicate that while the managers perceived that, despite the need to make up the quota, they did not take Saudis who did not conform to 
the hotel's criteria, the Saudi employees themselves did not have any particular difficulty in finding a job due to the shortage of Saudis to make up the Nitaqat quota in hotels. For Statement 9 , a clear majority $(70.9 \%)$ of managers agreed or strongly agreed that foreign hotel employees worked harder than did Saudi employees. However, only $58.4 \%$ of employees felt that hotel managers preferred to employ foreign workers to Saudis. This disparity could be attributed to the fact that managers are obliged to hire Saudi workers to fulfill the Nitaqat quota. It was revealed in the responses to Statement 10 that $70.9 \%$ of managers perceived there to be a high turnover of local employees in hotels.

The managers' perception was supported by the employees' responses: $41.6 \%$ of employees expressed the clear intention of moving to a job in another hotel in the near future, while half had not ruled out the possibility of doing so. The small differences in the mean scores for all three statements indicate that the responses of the two groups of respondents are similar.

However, one reason for the high turnover of employees in the hospitality sector in Saudi Arabia in particular was given by two of the managers in response to the open-ended question. Manager 16 stated that

In general, very few Saudis consider hotel work as suitable for them. (M16)

Similarly, Manager 2 expressed the opinion that

Saudis see hotel work as being of low status. (M2)

These findings are consistent with Albabtain's (2015) contention that social status is one of the most important factors for Saudis in their choice of employment. The findings imply that changing locals' attitudes towards hotel work is a factor which could assist in implementing the policy in this industry effectively. 


\section{Theme 5: Skills in hotel work}

The Likert scale statements relating to Theme 5, Skills in hotel work are shown in Table 6, together with the results of the analysis of the responses to these statements. Following this, the results of the responses to the open-ended question in which this theme emerged are also presented.

Table 6: Results of analysis of responses for Theme 5: Skills in hotel work

\begin{tabular}{|c|c|c|c|c|c|c|c|c|c|c|}
\hline & Statements & Position & & $\begin{array}{l}\text { Strongly } \\
\text { Disagree }\end{array}$ & Disagree & $\begin{array}{l}\text { Neither Agree } \\
\text { Nor Disagree }\end{array}$ & Agree & $\begin{array}{l}\text { Strongly } \\
\text { Agree }\end{array}$ & Total & Mean \\
\hline \multirow{4}{*}{11} & \multirow{4}{*}{$\begin{array}{l}\text { Practical training in } \\
\text { vocational schools can } \\
\text { help implement } \\
\text { localisation in hotels. }\end{array}$} & \multirow{2}{*}{ Managers } & Frequency & 0 & 0 & 0 & 16 & 8 & 24 & \multirow{2}{*}{4.33} \\
\hline & & & Percent & $0.0 \%$ & $0.0 \%$ & $0.0 \%$ & $66.7 \%$ & $33.3 \%$ & $100 \%$ & \\
\hline & & \multirow{2}{*}{ Employees } & Frequency & 0 & 0 & 1 & 16 & 7 & 24 & \multirow{2}{*}{4.25} \\
\hline & & & Percent & $0.0 \%$ & $0.0 \%$ & $4.2 \%$ & $66.7 \%$ & $29.2 \%$ & $100 \%$ & \\
\hline \multirow{4}{*}{12} & \multirow{4}{*}{$\begin{array}{l}\text { Hotels offer good } \\
\text { training and } \\
\text { development } \\
\text { programmes. }\end{array}$} & \multirow{2}{*}{ Managers } & Frequency & 0 & 0 & 4 & 15 & 5 & 24 & \multirow{2}{*}{4.04} \\
\hline & & & Percent & $0.0 \%$ & $0.0 \%$ & $16.7 \%$ & $62.5 \%$ & $20.8 \%$ & $100 \%$ & \\
\hline & & \multirow{2}{*}{ Employees } & Frequency & 0 & 4 & 3 & 9 & 8 & 24 & \multirow{2}{*}{3.88} \\
\hline & & & Percent & $0.0 \%$ & $16.7 \%$ & $12.5 \%$ & $37.5 \%$ & $33.3 \%$ & $100 \%$ & \\
\hline \multirow{4}{*}{13} & \multirow{4}{*}{$\begin{array}{l}\text { Saudis' English- } \\
\text { language skills are } \\
\text { adequate for hotel } \\
\text { work. }\end{array}$} & \multirow{2}{*}{ Managers } & Frequency & 1 & 4 & 6 & 11 & 2 & 24 & \multirow{2}{*}{3.38} \\
\hline & & & Percent & $4.2 \%$ & $16.7 \%$ & $25 \%$ & $45.8 \%$ & $8.3 \%$ & $100 \%$ & \\
\hline & & \multirow{2}{*}{ Employees } & Frequency & 2 & 7 & 2 & 9 & 4 & 24 & \multirow{2}{*}{3.25} \\
\hline & & & Percent & $8.3 \%$ & $29.2 \%$ & $8.3 \%$ & $37.5 \%$ & $16.7 \%$ & $100 \%$ & \\
\hline
\end{tabular}

There was little difference in the responses of the managers and employees to Statement 11 , with $100 \%$ of the former and $95.9 \%$ of the latter agreeing or strongly agreeing that practical training in vocational schools can help implement localization in hotels. The analysis of the data from Statement 12 showed that $83.3 \%$ of managers believed that hotels offered good training and development programmes, while $70.8 \%$ of employees agreed or strongly agreed that they were good. It appears that Saudi employees, as the recipients of the training programmes, perceive more deficiencies in these than do managers. This implies that no effective training needs analysis is being carried out in the hotels. A training needs analysis is a continuing process of collecting information to decide what needs for training exist and what programmes can be developed to deliver this training (Brown, 2002). 
In response to Statement $13,54 \%$ of both managers and employees agreed or strongly agreed that Saudis' English language skills were adequate for hotel work. This indicates that not only do managers perceive that Saudis require better English language skills (only around half agreed these skills were adequate), but employees themselves also feel that their English skills are inadequate for the jobs they do.

The highest difference in the mean scores of the managers and the employees for these statements is just 0.16 (for Statement 12), indicating that the two groups of respondents have similar views on skills in hotel work.

Responding to the open-ended question in the questionnaire, Manager 3 stated

They need to continue to revise the education system to make sure that Saudis' skills and general education are better aligned to the demands of the private sector. (M3)

Similarly, in response to the open-ended question, Employee 15 expressed the view that

Saudization could be improved by providing better training courses so there would be better human resources. (E15)

These findings support Todaro \& Smith's (2006) argument that Saudi nationals' skills (competencies) must be developed before the Saudization policy to be implemented effectively. Thus, the findings imply that skills development through education and training is a factor which would assist in implementing the policy in this industry effectively.

\section{Theme 6: Working conditions in the hotel industry}

The Likert scale statements relating to Theme 6, Working conditions in the hotel industry, are shown in Table 7, together with the results of the analysis of the responses to these statements. Following this, the results of the responses to the open-ended question in which this theme emerged are also presented. 
Table 7: Results of analysis of responses for Theme 6: Working conditions in the hotel industry

\begin{tabular}{|c|c|c|c|c|c|c|c|c|c|c|}
\hline & Statements & Position & & $\begin{array}{l}\text { Strongly } \\
\text { Disagree }\end{array}$ & Disagree & $\begin{array}{l}\text { Neither Agree } \\
\text { Nor Disagree }\end{array}$ & Agree & $\begin{array}{l}\text { Strongly } \\
\text { Agree }\end{array}$ & Total & Mean \\
\hline \multirow{4}{*}{14} & \multirow{2}{*}{$\begin{array}{l}\text { Saudis' salary } \\
\text { expectations in the hotel } \\
\text { sector are appropriate. }\end{array}$} & \multirow{2}{*}{ Managers } & Frequency & 0 & 3 & 5 & 14 & 2 & 24 & \multirow{2}{*}{3.63} \\
\hline & & & Percent & $0.0 \%$ & $12.5 \%$ & $20.8 \%$ & $58.3 \%$ & $8.3 \%$ & $100 \%$ & \\
\hline & \multirow{2}{*}{$\begin{array}{l}\text { Salaries in the hotel } \\
\text { sector are suitable for } \\
\text { Saudi employees. }\end{array}$} & \multirow{2}{*}{ Employees } & Frequency & 3 & 9 & 3 & 8 & 1 & 24 & \multirow{2}{*}{2.79} \\
\hline & & & Percent & $12.5 \%$ & $37.5 \%$ & $12.5 \%$ & $33.3 \%$ & $4.2 \%$ & $100 \%$ & \\
\hline \multirow{4}{*}{15} & \multirow{4}{*}{$\begin{array}{c}\text { Saudis do not want to } \\
\text { work long hours in } \\
\text { hotels. }\end{array}$} & \multirow{2}{*}{ Managers } & Frequency & 2 & 6 & 2 & 6 & 8 & 24 & \multirow{2}{*}{3.50} \\
\hline & & & Percent & $8.3 \%$ & $25.0 \%$ & $8.3 \%$ & $25.0 \%$ & $33.3 \%$ & $100 \%$ & \\
\hline & & \multirow{2}{*}{ Employees } & Frequency & 1 & 3 & 4 & 5 & 11 & 24 & \multirow{2}{*}{3.92} \\
\hline & & & Percent & $4.2 \%$ & $12.5 \%$ & $16.7 \%$ & $20.8 \%$ & $45.8 \%$ & $100 \%$ & \\
\hline
\end{tabular}

Statement 14 differed in the managers' and employees' questionnaires, as can be seen in Table 7. The responses showed that two-thirds (66.6\%) of managers agreed or strongly agreed that Saudis' salary expectations in the hotel industry were appropriate. However, only $37.5 \%$ of the employees agreed or strongly agreed that salaries in the hotel industry were suitable for Saudis, while $50 \%$ disagreed or strongly disagreed, indicating that half of the employees were not satisfied with their salaries. This was reflected in the difference of 0.84 between the mean scores of the two groups. The data from the managers' and employees' questionnaires to Statement 15 revealed that the two groups of respondents were in broad agreement that Saudis did not want to work long hours in hotels, as $58.3 \%$ of the managers agreed or strongly agreed, while $66.6 \%$ of employees did so. This disparity is also reflected in the small difference in mean scores.

In response to the open-ended question, Manager 6 suggested that

Saudi employees usually want to start with a high salary and don't want to be patient to work their way up. They usually want longer holidays as well. (M6)

Similarly, Employee 2 stated

Saudization would be easier if jobs offered higher salaries, more job security, health insurance, incentives and social security. (E2) 
The findings support Alhejji and Garavan's (2016) suggestion that Saudis preference for the public sector could be due partly to their being such a discrepancy in benefits and working conditions between the private and the public sectors.

Greater parity between working conditions in the public and private sectors is therefore indicated as a factor which would assist in implementing the policy in the 4- and 5-star hotel industry effectively.

In the following section, conclusions are drawn in the light of the findings.

\section{CONCLUSION}

The purpose of this paper was to explore the issues involved in effectively implementing the localization policy in the 4- and 5-star hotel industry in Saudi Arabia.

It was specified that, in order to be effective, the implementation of the localization policy should be measured not only quantitatively, but qualitatively, in accordance with Potter's (1989) definition. Thus, the first objective, to specify criteria for the effective implementation of localization policies, was fulfilled. In relation to this objective, it is noted that the Nitaqat programme measures success in quantitative terms only without considering the qualitative aspect. Hence, if hotels manage to attract sufficient numbers of local employees to fulfill the quota, this is does not mean that these employees will necessarily be competent to undertake the job. This was reflected in SCTA3's claim in Phase I that sometimes hotels could not find suitable Saudi candidates and had to employ any Saudi to make up the Nitaqat quota.

The second objective, to identify the issues involved in implementing the localization policy in the 4- and 5-star hotel industry in Saudi Arabia, was accomplished. From the findings of the empirical work, the following issues were found to be involved in the 
effective implementation of the localization policy in four- and five-star hotels in Saudi Arabia: Lack of awareness of career opportunities in the hotel industry; Scarcity of Saudi women in hotel work; Locals' attitudes; Skills shortage; Disparity between working conditions in public and private (e.g. hotel) sectors.

The third objective, to determine factors which could assist in implementing the Saudization policy in this industry effectively, was fulfilled by the identification of the following factors through the findings from the empirical work. These factors were identified as: raising awareness of potential careers in the hotel industry; increase in Saudi women's participation in the hotel workforce; greater government support to the hotel industry skills development of human capital through education and training; greater parity between holidays, working hours and salaries in public and private (e.g., hotel) sectors.

\section{Implications}

The findings have several implications for theory and practice. One implication of the findings is that if there was greater awareness of the potential for careers in the hotel industry, hotel managers would be able to recruit from a wider talent pool and would therefore be able to meet the Nitaqat quotas without resorting to hiring unsuitable candidates. Saudization in the hotel industry would hence be more effective, in terms of Potter's (1989) criteria.

A further implication is that, while an increase in the employment of Saudi women in the hotel workforce would help hotels fulfill the Nitaqat quotas, there are cultural and practical barriers which must be overcome in order to attract more women to this type of employment. In addition, the findings imply that if the Saudi government maintained or raised the subsidies given to hotels to employ local workers, this would serve to attract more Saudis to work in hotels without the hotels incurring extra costs. However, even with the 
wage subsidies, not enough Saudis are attracted to hotel work and the subsidies are not a long-term solution to the effective implementation of Saudization in the hotel industry.

The findings further imply that it is difficult for 4-and 5-star hotels to find suitable Saudi candidates to meet the Nitaqat quotas, suggesting that the government should review the quotas. The development of human capital through education and training could assist in providing a larger local talent pool for hotels to recruit from.

Moreover, according to the findings, hotel managers are reluctant to offer Saudi employees extensive training for fear they will leave the job soon after training and indeed, over $40 \%$ of employees expressed a clear intention of moving to a job in another hotel. Nonetheless, this reluctance on the part of managers is perhaps paradoxical, as there is evidence to suggest that well-developed and appropriate training programmes promote organizational commitment (Jehanzeb, Rasheed, \& Rasheed, 2013). Hence, training, determined through training needs analyses could potentially enhance the retention rates of Saudi employees in the hotel industry. However, employee turnover in the hospitality sector is among the highest of any sector worldwide (CHA International, 2009) so this phenomenon is not unique to Saudi Arabia. In this light, it could be suggested that, while hotels should take steps to improve employee retention rates, realistically, they should also be prepared for a certain volume of staff turnover.

A further implication of the findings is that if hotels offered Saudi hotel employees the salaries, working hours, holidays and job security that they would like, they would be likely to attract and retain more Saudi workers. This finding supports Vasquez's (2014) contention that "When top management strives to fulfill workers' needs and provides some assurance of job security or advancement, the desire to stay augments significantly" (p.2). However, providing the ideal working conditions for Saudis would be costly, and thus inconsistent with 
hotels' business requirements and necessity to make a profit for their owners. In addition, due to the nature of the hotel business, regular working hours would be impractical for hotel employees. Thus, it may be inferred that it could be unrealistic for all the ideal working conditions of Saudi employees to be fulfilled.

\section{RECOMMENDATIONS}

A further implication of the findings is that they were used to develop several recommendations for government policy makers and hotel management which may assist in promoting effective localization in the hotel industry in Saudi Arabia. These are the following:

\section{Recommendations for Government Policy Makers}

Awareness of the potential for careers in the hotel industry should be raised by communicating the attractions of careers in the hotel industry. Schools and colleges should develop and introduce career planning and career guidance programmes, as currently, these are not well integrated in the education system in Saudi Arabia. Government agencies could also extend their activities at job fairs and similar events, as well as engaging in media campaigns to encourage local people to take up careers in the hotel industry. Raising awareness of the potential for careers in hotels includes raising awareness of the fact that there are many jobs in hotels suitable for women in that they are compatible with Islamic values.

It is further recommended that structures be put in place to bridge the gap between the hotel industry and education. Curricula of tourism and hospitality courses in vocational schools, colleges and universities should be developed in consultation with professionals in the field in order to be better aligned with the needs of the industry. Practical, hands-on 
experience should also be part of these curricula. This could take the form of work experience programmes or weekend/holiday jobs for students, as this practice is currently unknown in Saudi Arabia.

Due to the difficulty that hotels currently experience in finding suitable Saudi candidates, it is recommended that, until there is a larger local talent pool for hotels to choose from, the government should review the Nitaqat quotas and introduce Saudization more gradually in this industry.

\section{Recommendations for Hotel Management}

It is suggested that hotels introduce part-time and flexible working arrangements such as jobsharing for both men and women. Currently, part-time work and flexible work arrangements are all but unknown in Saudi Arabia. Such arrangements would encourage local women take up to employment in hotels while having sufficient time to attend to their family responsibilities. In addition, hotels should provide facilities separate from men for local female employees to encourage them to enter the hotel industry.

It is further recommended that, rather than raising salaries for local employees, hotels introduce a system of bonuses and rewards based on performance. This could attract locals who are deterred by the comparatively low salaries in entry-level positions in the hotel industry. At the same time, it would offer an incentive for local employees to be (as perceived by hotel managers) as hard working and productive as foreign workers. This would be of benefit to the hotels without their having the outlay of higher salaries across the board. However, this would also require hotels to develop effective performance appraisal schemes.

The nature of the hotel industry means that shift work is necessary for the majority of jobs and it would be impossible to give all employees time off on public holidays, for 
example. However, it is suggested that hotels offer their employees more paid annual leave to bring them closer to the more extensive annual leave entitlement offered by the public sector. This could serve to attract more Saudis to hotel work. While this would represent a considerable outlay for hotels, it may serve to reduce staff turnover. Thus, hotels would make savings on recruitment costs.

\section{LIMITATIONS AND FUTURE RESEARCH}

This paper makes a contribution to understanding the issues facing the hotel industry in Saudi Arabia in relation to the government's Saudization policy. However, there are a number of limitations to be considered, together with potential avenues for further research in this area.

Phase II of the research was carried out in two cities, Riyadh and Jeddah; the work focused on 4- and 5-star hotels and the sample was 24 managers and 24 employees. Future research could survey other cities and/or two- and three-star hotels in Saudi Arabia to discover any similarities or differences in views compared to the present study. In addition, increasing the number of managers and employees surveyed could add further value and insight.

Regarding the Phase II questionnaire, the nature of the Likert scale statements did not allow respondents to elaborate on the reasons for their responses, and the extent to which they were able to do this in response to the open-ended question was limited. It is therefore suggested that a follow-up study be conducted, using in-depth interviews to extend this present study.

In this present research, the research participants were managers and employees of hotels in Saudi Arabia. It is suggested that the research be extended to include policy makers in these countries. Finally, the effective implementation of localization policies is of concern 
across the GCC countries; it is suggested the hotel industry in other GCC countries be surveyed to enable comparisons with the findings of this research.

\section{REFERENCES}

Al Ahsa Chamber (2014). Nitaqat Guidelines (in Arabic). Al Hofuf: Al Ahsa Chamber.

Al-Asfour, A., \& Khan, S. A. (2014). Workforce localization in the Kingdom of Saudi Arabia: issues and challenges. Human Resource Development International, 17(2), 243-253.

Al-Munajjed, M., \& Sabbagh, K. (2011), Youth in GCC Countries: Meeting the Challenge. New York: Booz \& Company Inc.

Albabtain, E. (2015). Correlates of Saudi Male and Female Students Work Values and Organizations' Desirability. PhD thesis submitted to University of Ottawa, Canada.

Albassam, B. A. (2015). Economic diversification in Saudi Arabia: Myth or reality?, Resources Policy, 44, 112-117.

Aldosari, K. A. (2013). Saudization in the Hospitality Industry: Management Issues and Opportunities. Unpublished doctoral dissertation. Melbourne, Australia: Victoria University.

Alhejji, H. A. \& Garavan, T. N. (2016). Human Resource Development in the Middle East. In Garavan, T. N., McCarthy, A. M. and M. J. Morley (Eds.). Global Human Resource Development: Regional and Country Perspectives. Abdingdon: Routledge, pp. 148167.

Aljazira Capital (2015). Saudi Hospitality Sector Report. Retrieved 20 November, 2015, from http://www.aljaziracapital.com.sa/report file/ess/SEC-196.pdf.

Aljubaili, S. (2015). Graduate Student Profile of Saudi Arabian Students Enrolled in the Hospitality and Tourism Management Program at RIT. Unpublished Master's dissertation. Rochester, USA: Rochester Institute of Technology.

Alotaibi, J., Paliadelis, P. S., \& Valenzuela, F. R. (2015). Factors that affect the job satisfaction of Saudi Arabian nurses. Retrieved 11 January, 2016, from http://onlinelibrary.wiley.com/doi/10.1111/jonm.12327/full.

Alshanbri, N., Khalfan, M., \& Maqsood, T. (2014). Nitaqat program in Saudi Arabia. International Journal of Innovative Research in Advanced Engineering, 1(10), 357366. 
Alsheikh, H. M. (2015). Current progress in the nationalization programmes in Saudi Arabia. Jeddah: European University Institute and Gulf Research Center.

Baki, R. (2004). Gender-Segregated Education in Saudi Arabia: Its Impact on Social Norms and the Saudi Labor Market. Education Policy Analysis Archives, 12(28), 1-12.

Baqadir, A. A. (2013). A skills gap between industrial education output and manufacturing industry labour needs in the private sector in Saudi Arabia. Unpublished doctoral thesis. Glasgow, UK: University of Glasgow.

Baqadir, A. Patrick, F., \& Burns, G. (2011). Addressing the skills gap in Saudi Arabia: does vocational education address the needs of private sector employers?, Journal of Vocational Education \& Training, 63(4), 551-561.

Bobanovic, M. K., \& Grzinic, J. (2011). The importance of English language skills in the tourism sector: A comparative study of students/employees perceptions in Croatia. Journal of Tourism, Culture and Territorial Development, 1(4), 10-23.

Brdesee, H., Corbitt, B., Pittayachawan, S. Alsaggaf, W., \& Brooks, S. (2012). Organizational Culture and Adoption of Electronic Commerce: A Study of the Saudi Arabian Tourism Market. Paper presented at the $7^{\text {th }}$ International Conference on Computer Science \& Education (ICCSE 2012), Melbourne, Australia, July 14-17.

Brown, J. (2002). Training needs assessment: A must for developing an effective training program. Public Personnel Management, 31(4), 569-578.

CHA International (2009). The Employee Turnover? The challenge. Retrieved 20 November, 2015, from http://www.cha-international.com/The-Hotel-Employer-Turnover.

Collier's International Tourism (2014). Saudi Arabia Tourism Opinion Piece. Retrieved 08 December, 2015, from http://www.colliers.com/ /media/files/emea/uk/research/destination-consulting/saudiarabia-tourism-overview.pdf.

DLA Piper (2012). Be Aware: Focus on Kingdom of Saudi Arabia. Retrieved 16 August, 2015 , from https://www.dlapiper.com/ /media/Files/Insights/Publications/2012/06/Focus\%20on\% 20Kingdom $\% 20$ of $\% 20$ Saudi $\% 20$ Arabia/Files/Be_Aware_Middle_East_June 2012/File Attachment/Be_Aware_Middle_East_June_2012.pdf.

DLA Piper (2015). Be Alert Middle East: New Saudi Labour Law. Retrieved 20 November, 2015, from https://www.dlapiper.com/en/uk/insights/publications/2015/06/be-alertmiddle-east-new-saudi-labour-law/. 
Fakeeh, M. S. (2009). Saudization as a Solution for Unemployment: The Case of Jeddah Western Region. Unpublished doctoral dissertation. Glasgow, UK: University of Glasgow.

General Authority for Statistics (2015). General Authority for Statistics Kingdom of Saudi Arabia. Retrieved 17 April, 2016 from http://www.stats.gov.sa/en/node.

Gummesson, E. (2000). Qualitative methods in management research. London: Sage.

Harry, W. (2007). Employment creation and localization: the crucial human resource issue for the GCC. International Journal of Human Resource Management, 18(1), 132-146.

Hay Group (2012). Nitaqat in the Spotlight. Retrieved 17 August, 2015, from http://www.haygroup.com/downloads/uae/Nitaqat in the Spotlight - Copy.pdf.

Hines, C. (2000). Localization: A Global Manifesto. London: Earthscan.

Hussain, S. (2015). Saudi Arabia's hospitality boom. Retrieved 08 April, 2016, from http://www.gulfbusiness.com/articles/country/saudi-arabia/saudi-arabias-hospitalityboom/.

HVS (2012). 2012 Middle East Hotel Survey. Dubai: HVS.

International Monetary Fund (IMF) (2013). Saudi Arabia: Selected Issues. Retrieved 11 July, 2016, from www.imf.org/external/pubs/ft/scr/2012/cr12272.pdf.

Jehanzeb, K., Rasheed, A., \& Rasheed, M. F. (2013). Organizational Commitment and Turnover Intentions: Impact of Employee's Training in Private Sector of Saudi Arabia. International Journal of Business and Management, 8(8), 79-90.

Jamjoom, F. B. \& Kelly, P. (2013). Higher education for women in the Kingdom of Saudi In L. Smith and A. Abouammoh (eds.), Higher Education in Saudi Arabia, Dordrecht: Springer, pp. 117-125.

Kluve, J. (2010). The Effectiveness of European Active Labor Market Programs. Labour Economics, Vol. 17, No. 6, pp.904-918.

Leeth, J. (2014). Integrating Saudi Women into the Workforce Brings Challenges. Virginia, USA: Society for Human Resource Management.

MAS (2011). Tourism Statistics (in Arabic). Retrieved 08 December, 2015, from http://www.mas.gov.sa/ar/publications/Publications2/00001902/09032014\%20ArabicTourism\%20Establishments \%20Statistics\%202012-HN 1.0.0.pdf.

MAS (2016). Accommodation establishments. Retrieved 06 April, 2016, from http://www.mas.gov.sa/en/KSAFocus/Pages/Dashboard.aspx. 
Mashood, N., Verhoeven, H., \& Chansarkar, B. (2009). Emiratization, Omanization and Saudization - common causes: common solutions?. Paper presented at the $10^{\text {th }}$ International Business Research Conference, Dubai, UAE, 16-17 April 2009.

Mayaka, M., \& Akama, J. (2007). Systems Approach to Tourism Training and Education: The Kenyan Case Study. Tourism Management, 28(1), 298-306.

Mehdizadeh, N. (2011). Gender and reconciliation of work and family in Iran. International Labour Review, 150(3-4), 405-417.

Patrick, F. (2014). Making the transition to a knowledge economy and knowledge society. In A. W. Wiseman, N. H. Alromi, \& S. Alshumrani, S. (eds.), Education for a Knowledge Society in Arabian Gulf Countries (pp. 229-251). Bingley: Emerald Group Publishing Limited.

Peck, J. R. (2015). Can Hiring Quotas Work? The Effect of the Nitaqat Program on the Saudi Private Sector. (Working paper). Cambridge, Massachusetts: Massachusetts Institute of Technology.

Potter, C. C. (1989). Effective Localization of the Workforce: Transferring Technology in Developing Countries, Journal of European Industrial Training, 13(6), 25-30.

Qureshi, R. (2014). Human resources development and the status of women labor force in Saudi Arabia: a critical analysis. International Journal of Current Research and Academic Review, 2(4), 144-155.

Redvers, L. (2015). Keys to the Kingdom: The slow rise of Saudi women. Retrieved 27 October, 2015, from http://www.bbc.com/capital/story/20150408-slow-gains-for-saudiwomen.

Robles, M. M. (2012). Executive perceptions of the top 10 soft skills needed in today's workplace. Business Communication Quarterly, 75(4), 453-465.

Saudi Ministry of Labor (2014). Statistical Yearbook 2014. Riyadh: Ministry of Labor.

Scott-Jackson, W., Kariem, B., Porteous, A., Harb, A. \& Rowley, C. (2013). Maximising the Employment of Saudi Females. Oxford: Oxford Strategic Consulting.

Shediac, R., Hoteit, D. L., \& Jamjoom, D. M. (2013). Listening to Students' Voices: Putting Students at the Heart of Education: Reform in the GCC. New York: Booz and Company.

Singh, A., Jones, D. B., \& Hall, N. (2012). Talent management: A research based case study in the GCC region. International Journal of Business and Management, 7(24), 94-107. 
Sullivan, K. (2012). Saudi Arabia struggles to employ its most-educated women. Retrieved 15 March, 2016, from http://www.independent.co.uk/news/world/middle-east/saudiarabia-struggles-to-employ-its-most-educated-women-8312035.html.

Todaro, M. P., \& Smith, S.C. (2006). Economic Development ( $9^{\text {th }}$ ed.) London: Longman.

Vasquez, D. (2014). Employee retention for economic stabilization: A qualitative phenomenological study in the hospitality sector. International Journal of Management, Economics and Social Sciences, 3(1), 1-17.

Warhurst, C., \& Nickson, D. (2007). Employee experience of aesthetic labour in retail and hospitality. Work, Employment \& Society, 21(1), 103-120.

Yusuf, N. (2014). Tourism development in Saudi Arabia. Journal of Business \& Retail Management Research, 8(2), 65-70. 